\title{
Mapping Digital Media and Journalism in Spain
}

\author{
Carles Llorens \\ Universidad Autónoma de Barcelona \\ carles.llorens@gmail.com \\ Virginia Luzón \\ Universidad Autónoma de Barcelona \\ virginia.luzon@uab.cat
}

\author{
Helena P. Grau \\ Universidad Autónoma de Barcelona \\ helpugra@gmail.com
}

\begin{abstract}
This article is based in a large-scale comparative study on Spanish Media digitalization funded by the Open Society Media Program. ${ }^{1}$ It shows how digital technology impacts on media newsrooms; on journalist ethics and on how investigative journalism have shaped Spanish media and how it is mixed with media economic crisis. It details trends in news websites' and their audiences; how online media outlets have proliferated, how consolidated media groups lead internet news audience rankings, and how newly created digital online outlets suffer from a lack of resources and branding. Internet's role as the space for public expression and it's importance of Spanish digital mobilizations is as well analyzed. Our analysis suggests that social media in Spain do have the potential to achieve significant mobilization, but developing this potential will depend on the prior existence of 'offline' reasons for mobilization, on simple and visible public appeals, on viral reproduction, and on the amplification of protests by legacy media.
\end{abstract}

Keywords: Media, Digital Media, Journalism, Digital Mobilizations and Social Networks

Resumen. $X x x \times x \times x \times x \times x \times x$

Este artículo se basa en un estudio comparativo a gran escala sobre la digitalización de los medios de comunicación españoles, financiado por el Programa de Medios de la Open Society. Muestra cómo la tecnología digital impacta en las redacciones de los medios de comunicación y en la ética de los periodistas y de qué forma el periodismo de investigación ha dado forma a los medios de comunicación españoles y cómo se mezclan con la crisis económica los medios de comunicación. En él se detallan las tendencias en los sitios web de noticias y sus audiencias, cómo los medios de comunicación en línea han proliferado, cómo los grupos de medios de comunicación consolidados lideran el ranking de internet de noticias de la audiencia y cómo los puntos de venta digitales en línea de nueva creación sufren de una falta de recursos y de la marca. También se analiza el papel de internet como espacio de expresión pública y la importancia de las movilizaciones digitales españoles. Nuestro análisis sugiere que los medios sociales en España tienen el potencial de lograr una importante movilización, pero el desarrollo de este

1. The complete study is avaliable at: http://www.opensocietyfoundations.org/reports/ mapping-digital-media-spain 
potencial dependerá de la previa existencia de razones offline para la movilización, en llamamientos públicos simples y visibles, en la reproducción viral, y en la amplificación de las protestas de los medios tradicionales de comunicación.

Palabras clave: medios, medios digitales, periodismo, movilizaciones digitales y redes sociales

\section{Introduction}

Along with the rest of the economy, the Spanish media - especially the print media - are undergoing one of their most severe crises, following a decline in advertising revenue and the need to adapt to the digital world. Since 2009 , broadcast media takeovers and mergers have been made easier by reducing restrictions on ownership and introducing audience thresholds applicable only at the point of the merger. Online-only editions are both proliferating and disappearing in an unstable scenario. These reorganizations have added more uncertainty to an already precarious and overcrowded labor market: massive lay-offs were common in the media sector in 2009-2010, and continued on a smaller scale in 2011-12.

In the midst of this crisis, all terrestrial television channels went digital by law (3 April 2010), two years before the EU's switch-off deadline. The technical process was quick and smooth and it has been considered a success, even if some future spectrum adjustments will be needed. As a consequence, the number of available nationwide free-to-air (FTA) television channels increased from six to about 30 over the past two years. However, from an economic point of view, the crisis of advertising revenue seems to have rendered this new digital scenario totally unsustainable. ${ }^{2}$

Despite the growing popularity of social media, especially among young people, the majority of the viewing audience remains faithful to television as the main entertainment and news source, and the level of consumption has actually increased. At the same time, however, Spain has the second highest mobile broadband and smartphone penetration levels in the EU after Italy: market research indicates that 52.5 percent of people owned one such device as of January $2012 .^{3}$

Brief, economic crisis, digital change and social media expansion have obliged Spanish media to rethink their strategies and future. Leaving apart the deep economic crisis, this research shows how new technologies at the newsrooms have change journalist practices. Later, how social activism has used

2. J. Villanueva et al., La TDT: ¿un negocio imposible? (DTT: an impossible business?), Deusto, Barcelona, 2008. (hereafter, J. Villanueva et al., La TDT: ¿un negocio imposible?)

3. Comscore, press release, Number of European Smartphone Users Accessing News Surges 74 Percent Over Past Year, 22 March2012. Available at: http://www.comscore.com/Press_Events/Press_Releases/2012/3/Number_of_European_Smartphone_Users_Accessing_News_Surges_74_Percent_Over_Past_Year (Accessed 10 May 2012). (hereafter, Comscore, press release, Number of European Smartphone Users Accessing News Surges 74 Percent Over Past Year 
social media in a new way bypassing traditional media. Social media is making a fast progress as a mobilization tool and a complementary information media in Spain. Finally, impact of digital change is studied through the Spanihs online media news providers rankings.

\section{Methodology}

This research is based in the Mapping Digital Media project, which is being funded by the Open Society Foundations (OSF). This foundation promote values of pluralism and diversity, transparency and accountability, editorial independence, freedom of expression and information, public service (public interest), and high professional standards. This large research has covered until now 60 countries, therefore it's one of the most large research projects on media history. As a main objectives, this project aims to assess the global opportunities and risks in the light of above mentioned values that are being created for media by the switchover from analogue broadcasting to digital broadcasting and the emergence and growth of new media platforms, especially on the internet, as sources of news and information.

The methodology carried out in this research is based in a detailed template, which was discussed in several meetings with the country researchers during 2010 and 2011. This reasearch template contains around 90 questions regarding media, journalism and broadcasting. In order maximise the comparability of findings from different countries, and limit the subjectivity of the reports, the answers had to be based on data or on sources with information from other available sources to ensure a broad and more trustful results. This template has been applied to Spain in 2011 and 2012 and the part related with Spanish digital technology impact on journalism was based in research already published and a series of structured interviews with journalists from different traditional media. The aim of these interviews were to establish the role of new technologies in the journalist workflow. Thus, the questions were addressed, first, to asess the main technologic changes in the profession in the last 5 years; second, the impact of them in the workflow; third, their impact on sources and data available for journalism purposes; fourth, if there is more diversity and pluralism due to new digital paradigm, and lastly if the new digital media have imposed changes in the traditional ways to make journalism.

\section{Digitalization, Impact on Journalists and Newsrooms}

During the last years, differences between newsrooms in online-only media and those in the legacy media have been reduced to such an extent that they hardly exist. Both use the same production technologies. They differ in the particular content distribution platform through which they get to the end-user via a range of reception devices: TV and radio, paper, radio waves, personal computer or mobile handset. 
In the last years, newsrooms have been digitized all over the country not only the large, country-wide media, but also local media and production companies.

The first moves into digital news were made by the dominant traditional brands. Both in print and audiovisual media sectors, the wealthiest companies set up digital newsrooms working alongside traditional newsrooms. ${ }^{4}$ Later on, new digital-only media sprang up, sometimes with support from a powerful media group or as an independent enterprise by a group of journalists committed to a free media model. ${ }^{5}$ Currently, both kinds of media exist, and also a new third type: digital-only and financially supported by a media corporation. ${ }^{6}$ The important point is therefore where digital outlets originate: from a big traditional corporation or a new digital company. According to an unofficial Spanish Government media phone book, there are only 23 digital online news sites in Spain: 13 are digital-only enterprises and 10 are supported or owned by a traditional media corporation.?

Each newsroom has followed a different kind of convergence procedure. Big companies and public corporations have adopted a differentiated model. They have large, distinct newsrooms for each media outlet with no contact among them. Their output, though, can be shared. Each newsroom has its own special technology, resources, and journalists. One example is the public Catalan Broadcasting Corporation (Corporació Catalana de Mitjans Audiovisuals, CCMA), which encompasses different digital media: the Catalan Television Company (Televisió de Catalunya), the Catalan Radio Company (Catalunya Ràdio) and the news portal $3 \mathrm{cat} 24 . \mathrm{ca} .{ }^{8}$ Each one has its own newsroom and website, but television and radio content from the former two is shared and recombined in the latter. So far, 3cat24.cat also produces its own content, but on a much smaller scale and only in text form.

Small online-only news companies use multimedia language, and there is just one newsroom with the same journalists and technology for the whole workflow. An example is Vilaweb, ${ }^{9}$ the oldest online-only news outlet, which has a small newsroom (only 12 journalists) for its online newspaper and IP television, using multimedia language as a tool. ${ }^{10}$

4. The first two digital newspapers were Barcelona's dailies Avui and El Periódico, both in 1995.

5. The first was Vilaweb in 1995.

6. One example is Lamalla.

7. Presidencia del Gobierno. Agenda de la Comunicación (Communication phone book). Gobierno de España, Madrid, 2011, available at http://www.agenciasaeacp.es/publicaciones/docs/AGENDA2011.pdf (accessed 20 April 2011).

8. Available at http://www.tv3.cat; www.catradio.cat; www.3cat24.cat (accessed 5 November 2010).

9. Available at http://www.vilaweb.cat (accessed 5 November 2010).

10. R. Salaverría, \& S. Negredo, Periodismo integrado: convergencia de medios y reorganización de redacciones (Integrated journalism: media convergence and Newsroom), Sol90Media, Barcelona, 2008. M.A. Cabrera, Evolución Tecnológica y Cibermedios (Technological developments and Cybermedia), Comunicación Social y Ediciones, Sevilla, 2010. 
Another difference between the digital media from a big or traditional news company and those from digital-only media is the content that they can afford. The former have big newsrooms and economic resources that enable them to produce their own news. For example, Rtve.es updated on a minute-by-minute basis news stories about the air traffic controllers' strike in December 2010. ${ }^{11}$ The new online-only digital media do not have these economic and human resources, so they rely on agencies to produce news. They can compete on local news and opinions. The latter are used to draw audiences' attention by including columnists that follow a particular editorial line and write more freely than in the traditional media. In the same air traffic controllers' strike, the online-only news outlet Libertad Digital posted agency information and a wealth of journalistic opinions, which were followed by thousands of audience comments. ${ }^{12}$

According to interviews with 10 editors from the main Spanish onlineonlyoutlets, direct interaction with the audience (through a visitors' counter system or users' comments on the site) appears to facilitate an immediate follow-up response. Editors stress that they can modify the news and adapt their content to audience demands. This carries risks and advantages unknown to traditional media. The first advantage is the ability to cater to audience needs, creating specialized contents, improving the update of news, and analyzing public responses. On the other hand, editors say that there is a risk in trivializing the news, because the public often follows sensationalist criteria, demanding scandals, stories involving sex and violence, etc. that respond to short-term curiosity but not to information needs aimed at the construction of a critical and democratic society.

Editors underlined as well the audience's role as a source through its interaction using the new digital tools. Audiences can be primary sources of information thanks to mobile phones or other communications devices. This means an increase in the number of witnesses and sources, which at the same time poses a risk because it is hard to verify these sources. One example was the news coverage of the conflict in the Sahara in November 2010, where new technologies allowed witnesses to provide newsrooms with pictures and information on invasions of encampments. In the case of this particular story, the media had evidence and material and thus could skip the information blockade imposed by the Moroccan Government. But not all the information was true: some people close to the Polisario Front sent to the newsrooms a picture of a group of children who had allegedly been wounded by the Moroccan army. In reality, however, they had been injured during the Palestine conflict. ${ }^{13}$ Almost all digital media published the picture without verifying the information or the source.

11. Available at http://www.rtve.es (accessed 4 December 2010).

12. Available at http://www.libertaddigital.com (accessed 4 December 2010).

13. Available at http://www.periodistadigital.com/periodismo/prensa/2010/11/13/propagandamanipulacion-periodismo-foto-el-aaiun-el-pais-el-mundo-abc.shtml (accessed December 2010). 
According to the editors surveyed, digital newsrooms save money for media corporations. The working conditions of digital journalists are different from those of standard journalists. They have lower salaries but are expected to multitask, a new condition that is not included in traditional union agreements. There is a new professional figure, "the digital journalist", who is witnessing a continuing change in his or her job description. Since the fading of specialization, working hours have tended to go up and salaries go down. As an example, a regional broadcaster like Televisió de Catalunya or Canal Sur Televisión pays a digital journalist half the standard salary. Paradoxically, the new digital media, with lower production costs, are unable to attract big advertising revenues and are forced to survive at the cash flow limit, with journalists living on low salaries and providing unpaid contributions. However, the future might be brighter if the Spanish internet advertising market follows other mature markets. At the moment, internet media hold a 13 percent share of the whole Spanish advertising market, compared with a 24.3 percent in the UK. ${ }^{14}$ But it is also true that advertising investment in Spanish digital media is growing twice as fast as in the UK and the United States.

\subsection{Ethics on online news?}

With respect to the impact of digitization on the ethical behavior of journalists, this is not yet visible in deontological codes. Only the Catalan Professional Journalists' Association (Collegi de Periodistes de Catalunya) attempted to start a debate in 2000 on the use of internet resources "in order to reach an agreement on all the problems we may have when writing an Internet Ethical Code. Among them, advertising, hypertext links, e-commerce, image manipulation, copyright, privacy, impartiality, accuracy and credibility in on-line news". ${ }^{15}$ There are a few deontological codes that include the use of internet resources, like those in the daily El Correo Gallego, the media group Vocento, Barcelona's local television station, Barcelona TV, and the Catalan public broadcaster, Corporació Catalana de Mitjans Audiovisuals. ${ }^{16}$ But none of them sets out how to use internet resources to improve journalism or what uses the journalist must avoid.

14. Marketing y comunicación IAB Spain. Interactive Advertising Bureau, available at http://www. iabspain.net (accessed December 2010).

15. Available at http://www.periodistes.org/documents_codi_deontologic (accessed 1 November 2010).

16. J.L. Mico; J. Canavilhas; P. Masip \& C. Ruiz, "La ética en el ejercicio del periodismo: Credibilidad y autorregulación en la era del periodismo en Internet", Estudos em Comunicaşao, no. 4, 2008, pp. $15-39$. 


\section{Opportunities and threats to Investigative Journalism}

According to the above-mentioned editors, digital tools (Twitter, search engines, etc.) present an opportunity for journalists to improve their research methods, but they are not as yet widely used. Only journalists with a strong interest in new technology use them on a regular basis.

While professional working practices remain largely unchanged, there are new ways of compiling, storing, indexing and recovering information. The quantity of data has increased. Information needs to be collated and sorted by relevance, and stored in new digital servers. A good index system is important for finding information and also for speedy data recovery. Digital tools allow for storing and searching information are indispensable. Integrated news content management software, such as Dalet ${ }^{17}$ - used at the public radio broadcaster, RNE—-makes it possible to have a networked newsroom, with an archive and a mechanism to retrieve any previously broadcast radio program. According to RNE journalist Rosa Cervantes, "When I have to make a report on any topic, the pre-production time is now reduced by a quarter. In my terminal I can locate within a very few minutes all the reports, interviews and news items that have already been produced on that same topic." ${ }^{18}$

But the interviewees for this report also asserted that digitization can give rise to new problems for journalistic working practice:

- Overabundance of sources and resources. Investigative journalists need to deal with the challenges of news selection and verification amidst the explosion of sources and nformation. Only training in the use of search engines and experience in news selection makes a journalist into an effective researcher. Antoni Novella, a journalist on the program "Espai Internet" (Internet space), with the Catalan Broadcasting Corporation flagship channel TV3, explains: "In one day you can visit more than 100 pages and you are sure that you're missing one that is truly good-apart from the hundreds of email messages from people offering their website or blog to be in our program. There is not enough time to evaluate everything, you have to trust your instinct, your ability as a journalist to do the news selection." 19

- Editorial control. Integrated digital newsrooms grant editors real-time access to the overall work in progress. They can use this access to improve production routines and supervise contents in development. Moreover, when someone reads or modifies a colleague's output - whether a superior or a peer — this person leaves a digital print. This change in production routines has a direct effect on selfcensorship.

17. Available at http://www.dalet.com/ (accessed 1 April 2012)

18. Interview with Rosa Cervantes, RNE journalist, Radio Nacional Barcelona, January 2011.

19. Personal Interview, January 2011. 
- Lack of time. Time becomes a very important factor for in-depth journalism. Digital newsrooms require constant news updates, which can make the journalist lose perspective and make it nearly impossible to research topics in any depth. The story of a Dutchman who supposedly flew with mechanical wings was covered by many Spanish media outlets on 20 March 2012. ${ }^{20}$ Headlines such as "Leonardo's dream" (Antena 3 TV) or "A Dutchman becomes first man to fly like a bird" (La Vanguardia) showed how fake but cleverly edited online video could evade professional filters due to the lack of time to verify and the urgency to publish first.

- An audience with more information may not be better informed. The desire to provide rapid and plentiful news may result in the public being unable to assimilate and understand the information, and thus be truly well informed.

As far as we know, no new entrants in digital media are doing investigative journalism in Spain. One explanation for this may be the aforementioned tradition of being used by political and economic elites, which limits journalistic independence. There are further possible causes: the lack of resources and fear of legal consequences encourage opinions instead of investigation. It promotes superficial news treatment-by hinting on the basis of financial or political gossip —or news based on alleged leaks from official sources. Some of these digital online news media include: El Confidencial digital, La información, El plural digital, Libertad Digital, Nació Digital, E-Noticies, and El confidencial. ${ }^{21}$

In Spain, legacy media outlets are the only ones still generating investigative journalism, thanks to three fundamental elements: budget, staff, and contacts. They can be the first to get a scoop and the first in audience share, but television news is consumed hastily, and the print press stories, despite the social prestige they retain, are quickly forgotten. It is in this context that the online-only news outlets have concentrated not on producing original news, but on selecting and spreading stories from the traditional media.

20. Available at http://www.antena3.com/noticias/ciencia/ingeniero-holandes-consigue-volarcomo-pajaro-alas-impulsadas-sus-brazos_2012032000168.html; (accessed 1 April 2012)

Available at http://blogs.lainformacion.com/futuretech/2012/03/20/un-ingeniero-holandeshace-realidad-el-sueno-de-volar-como-un-pajaro-con-unas-alas-impulsadas-por-su-fuerzamuscular/ (accessed 1 April 2012)

Available at; http://www.entitulares.com/news/un-holandes-se-convierte-en-el-primer-hombre-en-volar-como-un-pajaro (accessed 1 April 2012)

21. Available at http://www.confidencialdigital.com; www.lainformacion.com; http://www.elpluraldigital.com; http://www.libertaddigital.com; http://www.naciodigital.cat; http://www.enoticies.com (accessed 26 January 2011). 


\section{Digital Media and Coverage of Sensitive Issues}

Spain is the only country in the EU that does not have a country-wide independent regulatory authority (IRA) for the communications sector. There are currently two regional media regulators: the Catalonia Audiovisual Council (Consell de l'Audiovisual de Catalunya, CAC), set up by the Catalan parliament in 2000, and the Andalusian Audiovisual Council (Consejo Audiovisual de Andalucia, CAA) set up in 2005. These bodies issue recommendations on sensitive matters and warn the media if there is a possible case of breach of audience rights. So far, the CAC has released three guides on information standards to be applied to immigration, violence against women and teenagers ${ }^{22}$ while the CAA has launched guidelines on the news treatment of immigrants, the youth, child advertising, sports violence, political news during electoral periods, media literacy, and news treatment of child murders. ${ }^{23}$

Sensitive matters have changed with social evolution itself. Ten years ago, homosexuality, AIDS, abortion, or same-sex marriages were sensitive matters, but reports about these topics are nowadays everyday occurrences. Other sensitive issues are terrorism, languages, and religion. With regard to terrorism, it should be recalled that since 1968 Spain is engaged in a separatist conflict with the Basque terrorist group, ETA. The only media shut down since the return of democracy have been those that have explicitly backed ETA's principles. ${ }^{24}$ The Basque Country conflict also had a coercive impact on journalism. Some national media outlets banned left-wing, pro-independence voices, which in turn boycotted certain outlets. For example, in 2007, "pro-Spanish" media were refused access to events of the left-wing pro-independence group, Basque Nationalist Action (Acción Nacionalista Vasca, ANV), which was outlawed the following year by the Spanish Supreme Court. ${ }^{25}$ On similar lines, elected municipal members of the Basque pro-independence group Bildu refused to allow journalists from certain Spanish media to access council as-

22. Available at http://premsa.gencat.cat/pres_fsvp/docs/2010/07/12/11/55/d63a40d6-baee48fd-8a2a-b4dfc7a14051.pdf; http://www.cac.cat/pfw_files/cma/recerca/quaderns_cac/ Q12recomanacions.pdf (accessed 10 December 2010); and http://www.observatorioviolencia. org/noticias.php?id=1130 (accessed 11 December 2010).

23. Available at http://www.consejoaudiovisualdeandalucia.es/actividad/actuaciones/recomendaciones (accessed 11 December 2010).

24. Eguin was closed in 1998 because of its links with ETA, Egunkaria was closed in 2003 but their managers were finally absolved in April 2010; the daily never reopened again, but it actually reappeared under a new name, Berria, in 2003.

25. El Mundo, "Lizarta veta a El Mundo y otros medios por haber manipulado la realidad del país" (Lizarta vetoes El Mundo and other media because they have manipulated the country reality), 11 June 2011, at http://www.elmundo.es/elmundo/2011/06/11/paisvasco/1307776489.html (accessed 10 July 2012). 
semblies. ${ }^{26}$ On the opposite side, the main Madrid based newspapers, El País and $\mathrm{ABC}$, have take sides against any concession to ETA in a way that some authors calls "media counter-terrorsim" with little respect to professional code of ethics. ${ }^{27}$ Another issue related to the independence and the Basque Country conflict was the manifestation of citizens on the streets of Bilbao the 5 of November of 2013 in support of the reunification of ETA prisoners which was treated very differently by the media. For example Telemadrid ${ }^{28}$ identify Bildu with the ilegalised Batasuna and also includes some pictures of ETA victims on the broadcast information, while others media, like Diario Vasco reflect that the facts were a "huge demostration"29.

Overall, most Spanish media outlets respect the limits of so-called "political correctness" in their editorial policies with a majoritary presence of institutional and national players and issues. ${ }^{30}$ They do not direct oppose particular groups, although debates are raised on controversial topics, such as the regulation of abortion, state aid to religious institutions or basque and catalan political issues ${ }^{31}$. There is a certain media unanimity in relation to sensitive social topics which transcend political ideologies, such as domestic violence, racism, and youth gang culture. However, positions are more radical on political, moral or religious issues, and online outlets are more likely to adopt or cover controversial positions than traditional outlets. ${ }^{32}$

26. Diario Vasco, "Bildu impide a los periodistas acceder al Pleno de Lizarta" (Bildu impedes journalist to access to the town council), 11 November 2011, at http://www.diariovasco.com/ rc/20110611/mas-actualidad/nacional/bildu-impide-periodistas-acceder-201106112126.html (accessed 10 July 2012).

27. P. Idoyaga; T. Ramírez. "Política informativa de El País y ABC ante la nueva situación política del País Vasco (1998-2000)”. Zer-Revista de Estudios de Comunicación, 6.10 (2012).

28. Telemadrid, "El Foro de Ermua pide, tras Herrira, que se ilegalice a los "continuadores de Batasuna" (The Ermua Forum asks, after Herrira, which outlaw the "followers of Batasuna"), 6 October 2013, at http://www.telemadrid.es/noticias/nacional/noticia/el-foro-de-ermua-pidetras-herrira-que-se-ilegalice-los-continuadores-de-b (accessed 11 November 2013)

29. Diario Vasco, "Decenas de miles de personas se manifestaron en Bilbao en protesta por la operación contra Herrira" (Tens of thousands of people rallied in Bilbao to protest the operation against Herrira), 5 October 2013, at http://www.diariovasco.com/20131005/mas-actualidad/ politica/bildu-llama-manifestarse-esta-201310051250.html

30. Casero, A., López, P. "La evolución de la agenda mediática española (1980-2010). Un análisis longitudinal de la portada de la prensa de referencia." Revista Latina de Comunicación Social, 67 (2012): 470-493.

31. Virgili, J. Sádaba, T. "La construcción de la agenda de los medios. El debate del estatut en la prensa española." Ambitos: Revista internacional de comunicación 16 (2007): 187-211.

32. Available at http://www.ara.cat/; http://www.naciodigital.cat/; http://www.vilaweb.cat; (accessed 4 April 2012). 


\section{Digital Activism: The web as the space for Public Expression, the social netwrosk as the space for activism}

The web and social networks have become a space for public expression, and sometimes a space for activism. However, social networks are more oriented to social-activism in Spain than in other countries. According to a specialized consultant firm, $17 \%$ of the 2012 Spanish trending topics in twitter were related to social movements as \#primaveravalenciana or \#ocupaelcongreso, whereas there was no presence of similar topics in the top 24 trending topics of other countries. ${ }^{33}$

Regarding websites, for exemple, when it comes to political independence supporters in Catalonia or the Basque Country, the internet and social media provide an easy opportunity for them to communicate and spread their ideas to citizens and social groups that might otherwise have been out of reach. ${ }^{34}$ The relative anonymity that the web offers or the impunity when voicing any type of opinion makes it possible for the most radical or even violent ideas to flourish in the comments sections of news sites, blogs, fora or social networking sites such as Facebook or Twitter. For instance, the live broadcast of a football match between teams representing antithetical nationalist positions gives rise to vitriolic and hateful speech online between respective supporters.

As a general conclusion, the most recent studies show that digital activism is making possible the creation of "new" news through social media use outside the boundaries established by the journalist and political elites and it represents an innovative strategy to brign new strong social demands onto the mainstream media and to instigate transparency and monitoring processes. However, the presence and importance of traditional media are still dominant. ${ }^{35}$

\subsection{Digital Platforms and Civil Society Activism}

Digital platforms are a good way for all those groups that have traditionally lacked a platform in traditional media to get their voice heard, specially the young. ${ }^{36}$ Three categories can be singled out: those groups defining them-

33. Europa Press, "España es el país que da más peso en Twitter a la política y movimientos sociales", available at http://www.europapress.es/portaltic/socialmedia/noticia-espana-pais-damas-peso-twitter-politica-movimientos-sociales-20130214113616.html

34. Available at http://www.racocatala.cat/; https://www.plataforma-llengua.cat/ (accessed 4 April 2012).

35. A. Casero; R. Andrés. "Nuevas formas de producción de noticias en el entorno digital y cambios en el periodismo: el caso del 15-M". Comunicación y Hombre, 8, (2012): 130-140; J. S. García. "Gobiernos en la calle y ciudadanos en las redes sociales: nuevas exigencias para el periodismo". Telos: Cuadernos de comunicación e innovación, 94, (2013): 58-67.

36. A. Rubio."El caso Spanish Revolution: Participación política de la juventud, redes sociales democracia digital.” Telos: Cuadernos de comunicación e innovación, 93, (2012): 106-115; M. Galera; M. Del Hoyo "Redes sociales, un medio para la movilización juvenil". Zer: Revista de estudios de comunicación, 34 (2013): 111-125. 
selves as "anti-establishment", the groups fighting "the establishment" from inside, and individuals organizing for specific causes.

With regard to the first group, anarchists and anticapitalists are organized under latent agendas, with intermittent outbreaks of calls for protests around, for instance, an international summit. Among those with a longer online tradition, the Spanish Indimedia, ${ }^{37}$ Kaosenlared, ${ }^{38}$ Alerta Solidaria, ${ }^{39}$ or Nodo $50^{40}$ stand out. All these portals bring together radical social protest, publicity for counter-information activities, and calls for civil disobedience.

Following the riots in Barcelona in October 2010, stirred by young antiestablishment protesters, the city authorities proposed to shut down websites encouraging violence on occasions such as police eviction of squatters or universities' adaptation to the new European Higher Education System. ${ }^{41}$ The groups responsible for these online organizations argued that each page or blog "is an intermediary and everything that is uploaded is the author's responsibility." 42 Sites warn that, even though there is no censorship before information is posted, they delete "illegal or offensive" content if someone demands it.

The groups working "inside the system" and using the web to disseminate their proposals and actions for social change include NGOs, users' or consumers' associations, and citizens' platforms. These resort to the web's viral capability to mobilize the civil population, with results that seem to have sometimes influenced political decisions.

37. Available at http://madrid.indymedia.org/; http://barcelona.indymedia.org (accessed 3 March 2011).

38. Available at http://www.kaosenlared.org (accessed 3 March 2011).

39. Available at http://www.lahaine.org (accessed 3 March 2011).

40. Available at http://www.nodo50.org/ (accessed 3 March 2011).

41. J. García, “¿Expulsar a los antisistema de Internet?” (Expel the anti-internet?), El País, 5 October 2010, available at http://www.elpais.com/articulo/cataluna/Expulsar/antisistema/Internet/ elpepuespcat/20101005elpcat_3/Tes (accessed 7 March 2011).

42. J. García, Internet, motor de los antisistema (Internet, the anti-system engine), El Pais, 7 October 2010, available at http://www.elpais.com/articulo/cataluna/Internet/motor/antisistema/ elpepiespcat/20101007elpcat_8/Tes (accessed 7 March 2011). 


\section{Sinde Law}

An example of political change initiated by internet action was the protest against the so-called Sinde Law, a section of the Sustainable Economy Law (Ley de Economia Sostenible, LES). This law intended to prosecute illegal downloading, streaming, and sharing of licensed content. The U.S. government put huge pressure on the Spanish Government to get the law passed, according to diplomatic cables released by WikiLeaks. ${ }^{43}$

The associations in favor of a free flow of internet information called for a protest in the form of the closure of all websites on 20 December 2010. The following day, the parliamentary commission in charge of the approval of the law rejected the shutting down of websites without the intervention of a judge. ${ }^{44}$

The internet users' associations, the association of small and medium size enterprises, and up to 20 more groups submitted an alternative proposal to the Senate Chamber. Among the proposed changes was the mandatory intervention of a judge to shut down websites, which was included in the final text, but this was to be only used as a last legal resort. 3 In the end, the controversial Sustainable Economy Law was passed in the Chamber of Deputies on 15 February 2011 with a 92 percent vote in favor, and published in the official gazette on 5 March 2011. It gives a government committee the power to blacklist internet sites trafficking in copyrighted files. However, a new regulation for that committee had to be drawn up in order to apply the new law, and again the level of digital activism was sufficient to hold up its approval until the new liberal government took office at the end of December 2011. The former Spanish President Rodríguez Zapatero has acknowledged that internet activism and internal cabinet differences were key to holding up the approval of this regulation. ${ }^{45}$

Another example was the protest against the decision of the RTVE Board to have access to the computer systems with information on editorial newscast decision-making in September 2011. The uproar in the social media, especially Twitter, was important for quickly reversing this decision in a new vote just two days later. However, it has to be said that traditional political and social reactions also played a significant role in changing the initial Board's position.

There are some exceptional cases in which the web works as a citizen's platform for independent individuals. An example is the Facebook page "Contra el residuazo del Ayuntamiento de Barcelona"46 ("Against Barcelona's local government big waste tax") created by a member of the public. ${ }^{47}$ The municipality announced that it would levy a tax on the self-employed working at home for the collection of industrial wastes. An individual citizen tried to mobilize the

43. N. Anderson, How the U.S. Pressured Spain to adopt unpopular Web blocking law, Ars Technica, 6 January 2012, available at http://arstechnica.com/tech-policy/news/2012/01/how-the-usconvinced-spain-to-adopt-internet-censorship.ars (accessed 8 January 2012).

44. Available at http://www.red-sostenible.net, (accessed 7 March 2011).

45. Available at http://aui.es/index.php?body=dest_v1article\&id_article=3371 (accessed 7 March 2011).

46. Available at http://www.facebook.com/pages/Contra-el-residuazo-del-Ayuntamiento-deBarcelona/104562959618146 (accessed 7 March 2011).

47. Available at http://www.establedentrodelagravedad.com/2011/01/20/el-ayuntamiento-debarcelona-remata-a-los-pequenos-autonomos-cobrando-por-residuos-ficticios/ (accessed 7 March 2011). 
self-employed to lodge an appeal against the municipality and reach the media. As a result of the media scandal, the local government modified the tax.

Finally, another case of citizen activism fostered by digital media is provided by Pablo Herreros, who blogs at Comunicacionsellamaeljuego.com. A specialist in media affairs, Herreros started a campaign on digital media in late 2011 to boycott a very popular late night entertainment program, "La Noria" (Ferris Wheel), on Telecinco. This program had paid $€ 10,000$ to interview the mother of a boy charged with murder. It was the last straw for a program with a history of dubious practices. The boycott called on "La Noria" advertisers to stop running their ads in this program. The response on the net was huge, more than 50 brands withdrew their commercials from "La Noria", and Telecinco changed the program's name to "El Gran Debate" (The Great Debate), and altered the concept to favor more social and political issues.

The case resurfaced in November 2012, when Telecinco took legal action against Herreros, demanding damages of $€ 3.6$ million to offset the losses incurred by the boycott. A digital initiative (based on Change. org) collected 169,000 signatures in 10 days, in support of Herreros. Telecinco withdrew its claim under this pressure, and in exchange for a joint declaration by Telecinco and Herreros which recognized that advertisers cannot be held accountable for messages by media companies. ${ }^{48}$

\subsection{The Importance of Digital Mobilizations}

Digital activist groups who challenged the Sinde Law were part of the origin of the democratic regeneration social movement, 15-M, developed in main squares of Madrid, Barcelona and other Spanish cities in May 2011. Its objective was to rethink and reform parliamentary democracy and capitalism, and it attracted a huge mass media attention during spring and summer 2011. The movement reached such an unprecedented size in Spain that all public authorities have been surprised and unable to react to the problem and neutralize its impact. However, as the movement is leaderless (because it supports direct democracy as a way to regenerate the political system), and its impact on parliamentary democracy has been limited, even if some left-oriented parties have adopted some of the movement's proposals.

According to Ismael Peña of the Open University of Catalonia (Universtat Oberta de Catalunya), "With no social media, the 15M movement would not have appeared." ${ }^{49}$ The ground for the emergence of the movement was prepared during several months of social media hostility to the Sinde Law. Its origin can also be traced in some alternative websites and blogs opposing the hegemonic political discourse, although with no specific party allegiance. It

48. See http://www.elmundo.es/elmundo/2012/11/27/comunicacion/1354041442.html

49. Available at http://www.noticiasdenavarra.com/2011/06/01/sociedad/navarra/el-15-mnacio-y-se-desarrollo-en-las-redes-sociales (accessed 2 April 2012). 
is in those social media that the main ideas and arguments were born which would later gather together in the broadbased movement. ${ }^{50}$ Their means of communication are Facebook, Youtube and Twitter. With these social media they disseminate manifestos and call for public demonstrations, of which the most successful were held simultaneously in the main Spanish capital cities on 15 May 2011. Later on, street camps and assemblies were formed in the most important Spanish squares to sustain and prolong the mobilization.

Two days after the 15 May demonstration, the Facebook page of Democracia Real Ya had 46,000 friends. By 20 May, they had amassed 180,000. The movement also projected its influence beyond the Spanish borders, and it received international support with the setting up of hundreds of sites from abroad: Sydney, London, Brussels, Hamburg, Santiago de Chile, Mexico FD. ${ }^{51}$ As some researchers have showed, the social networks use by this movements was key for its success, because of its contagion effect and its feedback to encourage more demonstrations and spread geographically the movement. ${ }^{52}$

However, not all popular mobilizations emerging in the social media are successful. The dissemination of some very cruel images on the death of a puppy, which is known as the Schnauzi case, brought about the campaign "No al maltrato animal" (Say no to animal mistreatment). The group called for public protests on 20 March 2012 with strong support from affiliated groups and associations online suggested. In the event, however, turnout was not as significant as was expected. ${ }^{33}$

\section{Mapping digital news providers}

It is difficult to identify trends in news websites' audiences due to the lack of agreement among industry players regarding which online audience measurement methods are most appropriate. ${ }^{54}$ For instance, since 2005 PRISA's

50. Available at http://www.adslzone.net/article6045-las-redes-sociales-impulsan-el-movimiento15-m-contra-la-clase-politica.html, and http://storify.com/pablobuentes/que-es-y-como-segesto-el-movimiento-15m (accessed 2 April 2012)

51. Available at http://blogs.lavanguardia.com/inspiracion-digital/2011/05/20/estudio-el-movimiento-15-m-y-las-redes-sociales-como-caldo-de-cultivo/ (accessed 2 April 2012).

52. Otero, T. P., \& Sánchez, C. C. "Ciberactivismo y redes sociales. El uso de Facebook por uno de los colectivos impulsores de la 'spanish revolution', Democracia Real Ya (DRY)”. Observatorio (OBS*), (2012) 6(3).

53. Available at http://www.scoobyzamora.org/concentracion.html (accessed 2 April 2012).

54. See El País, "La nueva OJD digital desata la polémica entre los grandes medios" (The new digital OJD unleashes controversy among big media), 13 March 2009, available at http:// www.elpais.com/articulo/sociedad/nueva/OJD/digital/desata/polemica/grandes/medios/ elpepisoc/20090313elpepisoc_7/Tes (accessed 10 March 2011); and Europa Press, "España, pionera en la medición híbrida de audiencias online" (Spain, a pioneer in a hybrid online audience system), 5 March 2011, available at http://www.europapress.es/portaltic/internet/noticiaespana-pionera-medicion-hibrida-audiencias-online-20110305080009.html (accessed 15 March 2011).. 
websites (Elpais.com, Cadenaser.com) have not been audited by the industry organization, the Interactive Circulation Audit Bureau (Oficina de Justificación de la Difusion interactiva, OJDi), which supervises more than 450 sites. However, PRISA has recently asked to be reincorporated in the audit. Likewise, Elmundo.es is not included in AIMC's EGM survey, based on more than 30,000 yearly interviews. Moreover, in 2009, OJDi, which uses a census-based method, adopted a Nielsen tool that does not correct the deletion of cookies.

This situation may change if the industry finally accepts a new Nielsen Online hybrid method, combining panel and census and using EGM's sample universe. The multinational has chosen Spain to apply it for the first time and issued its first results in January 2011 (see Table 5). Google News is not included in these results, however. Therefore, audience data from Google AdPlanner are shown (Table 6), The situation is further complicated by media outlets' habit of publishing total monthly figures for unique users, for marketing purposes, despite OJDi insisting on numbers of daily average unique users as the best tool to measure and compare sites' audience impact. ${ }^{55}$

Table 1. Online news media audience Ranking (January 2011), hybrid method (Panel + CENSUS)

\begin{tabular}{|l|l|l|}
\hline Rank & Media outlet/URL & $\begin{array}{l}\text { Monthly unique users } \\
\text { (millions) }\end{array}$ \\
\hline 1 & Elmundo.es & 5.6 \\
\hline 2 & Rtve.es & 4.3 \\
\hline 3 & Abc.es & 3.4 \\
\hline 4 & Telecinco.es & 3.2 \\
\hline 5 & Antena3.com & 2.9 \\
\hline & 20minutos.es & 2.9 \\
\hline 6 & Laverdad.es & 1.8 \\
\hline 7 & Elperiodico.com & 1.5 \\
\hline & Europapress.com & 1.5 \\
\hline & Es.noticias.yahoo.com & 1.5 \\
\hline & Cuatro.com & 1.5 \\
\hline 8 & Que.es & 1.4 \\
\hline 9 & Publico.es & 1.3 \\
\hline 10 & LibertadDigital.com & 1.1 \\
\hline
\end{tabular}

Source: Compiled from Nielsen Online/Ión Comunicación data 
TABle 2. Online news media audience RANKing (January 2011)

\begin{tabular}{|l|l|l|}
\hline Rank & Media Outlet/URL & $\begin{array}{l}\text { Montly unique users } \\
\text { (millions) }\end{array}$ \\
\hline 1 & Marca.com & 6.9 \\
\hline 2 & as.com & 5.6 \\
\hline 3 & elmundo.es & 5.6 \\
\hline 4 & elpais.com & 5.0 \\
\hline 5 & rtve.es & 4.2 \\
\hline 6 & telecinco.es & 3.1 \\
\hline 7 & antena3.com & 2.6 \\
\hline 8 & abc.es & 2.4 \\
\hline 9 & sport.es & 2.1 \\
\hline 10 & 20 minutos.es & 2.0 \\
\hline
\end{tabular}

Source: Google AdPlanner

The most visited news media sites seem to replicate the market shares of publishers and broadcasters offline. They include the national sport paper Marca; quality newspapers such as ElMundo, El Pais, ABC, and 20 minutos; and among broadcast media, Telecinco.es, Antena3.es, and Rtve.es, the latter being the leader among broadcasters in both tables. Nielsen's hybrid measurement includes some regional leaders such as La Verdad. Other sites worthy of note on Nielsen's table are third-party news aggregators or portals offering a wide range of content and services, including reworked, third-party, or self-produced hard and soft news (MSN, Yahoo or Terra.es).

However, some news websites committed to more serious journalism have emerged online. They usually are the result of the exploitation of new online platforms by independent journalists. Periodismo Humano, for example, was set up in 2010 by Pulitzer prize winner Javier Bauluz. Perhaps the most interesting was the shortlived Soitu.es. This site was launched in December 2007 and very soon had a half a million unique visitors a month and another two million users monthly through its third-party widgets. Despite its new approaches to a new on-line journalism with an important social part, the site closed after just 22 months, in October 2009, following a decision by its main financial backer and principal shareholder, the Spanish bank BBVA. ${ }^{56}$

56. L. Bennet, "Soitu.es couldn't find the business model to match its content creativity," Nieman Journalism Lab, 5 March 2010, Available at: http:/ /www.niemanlab.org/2010/03/soitu-es-couldnt-find-the-business-model-to-match-its-content-creativity/(accessed 15 May 2012). 


\subsection{News in Social Media}

With regard to news consumption and its relation to social media, Meneame.net ${ }^{57}$ is a good example of a Spanish bookmarking site where users can share the most relevant news references on the web and move them so that other users can also read and give them prominence. This site ranks 43 in Alexa's list.

As for the degree of novelty of the news in social media, a study by Apple Tree Communications on Twitter (March 2012) stresses that 86 per cent of Trending Topics in Spain "are mere repetitions of news stories coming from the legacy media." 58 Among the most important topics analyzed during 2011 there were mainly political and economic stories, along with sport and social news which derived from traditional media sources. This suggests that the news consumed through social media and blogs depends overwhelmingly on these sources whose content is often is embeded or linked to by social media users..$^{59}$

Finally, the rankings of Spanish blog sites suggest that they are mostly focussed on technology interests rather than news about politics or current affairs (see Table 3).

Table 3. Spanish Blogs Ranking by popularity July 2012

\begin{tabular}{|l|l|l|l|}
\hline Ranking* & Blog & Subject & $\begin{array}{l}\text { Thousands Users by month in Spain } \\
\text { According Google AdPlanner** }\end{array}$ \\
\hline 1 & ALT1040 & Technology & 240 \\
\hline 2 & FayerWayer & Technology & 150 \\
\hline 3 & Escolar.net & Politics & 180 \\
\hline 4 & El Comidista & Gastronomy & na \\
\hline 5 & Applesfera & Technology & 430 \\
\hline 6 & Amazings.es & Science & 77 \\
\hline 7 & Genbeta & Technology & 430 \\
\hline 8 & El Blog Salmon & Economy & 290 \\
\hline 9 & Microsiervos & Technology & 320 \\
\hline 10 & Xataka & Technology & 760 \\
\hline 11 & Gizmodo & Technology & 48 \\
\hline 12 & Yorokobu & Arts and Culture & 120 \\
\hline 13 & Engadget & Technology & 260 \\
\hline
\end{tabular}

57. Available at http://www.meneame.net (accessed 3 March 2011).

58. AppleTreeCommunications, Twitterscopio \#03, at http://dl.dropbox.com/u/2242091/appletree_Twitteroscopio03.pdf (accessed 1 April 2012).

59. Available at http://bitacoras.com/informe\#medios-enlazados (accessed 3 April 2012). 


\begin{tabular}{|l|l|l|l|}
\hline 14 & Apple Weblog & Technology & 180 \\
\hline 15 & Cooking Ideas & Technology & 85 \\
\hline 16 & $\begin{array}{l}\text { ReadWriteWeb } \\
\text { España }\end{array}$ & Technology & 140 \\
\hline 17 & $\begin{array}{l}\text { El blog de Enri- } \\
\text { que Dans }\end{array}$ & Technology & 100 \\
\hline 18 & Bitelia & Technology & 120 \\
\hline 19 & WWWhat's & Technology & 380 \\
\hline 20 & Xataka Foto & Technology & 160 \\
\hline
\end{tabular}

Source: *Ebuzzing. bttp://labs.ebuzzing.es/top-blogs and **Google AdPlanner(Accessed 10 July 2012)

With respect to social media, there is a debate about their contribution to good-quality news. Online media editors acknowledge that they can enhance research if used properly. However, everyday experience shows that journalists are still sceptical, especially in large, long-established corporations like RTVE. ${ }^{60}$ The Conference on Digital Journalism (Huesca, 10-13 March 2011) awarded web investigative reporting on the basis of traditional professional standards, while some expert digital journalists attending the meeting questioned why good journalism has to be identified with serious reporting as opposed to the superficial immediacy of social media.

\section{Conclusions}

Digitization has changed journalists' working practice, but it has not brought about an improvement in quality. We face a professional paradox: technologies and resources are available to journalists, but they cause a deterioration in their conditions of employment, which puts quality at risk. Salaries are lowered to cut down on production costs, and multitasking professional profiles are in demand instead of those permitting specialization. The process overloads journalists' work practices and allows the exercise of more editorial pressure.

There are more online media, both traditional and originating from digitalonly media, which has resulted in a proliferation of opinions, the representation of social minorities and greater political pluralism. However, digital media from digital-only origins promote superficial news treatment, and it is limited by an ideological partisanship shared with the audience. In the Spanish online media world, interpretation and opinion are more important than facts and data.

60. Interview with David Varona, social media manager and journalist at RTVE.es, 20 February 2011. 
Though internet user trends only reflect that part of Spanish society which has access to the technology required and uses social media, Spain has a real digital divide in online media consumption, and there is a substantial difference in the number of readers of the big media press online and that of digital dailies with a low market penetration. Digitization has enabled the expansion of social media and social movements that, outside traditional mainstream media, have had a certain influence on Spanish political and social life, such as the $15-M$ movement, launched with massive protests around the country on 15 May 2011, aimed at democratic regeneration.

\section{Bibliography}

Anderson, N. (2012). "How the U.S. Pressured Spain to adopt unpopular Web blocking law". Ars Technica, 6 January 2012, available at http://arstechnica.com/tech-policy/news/2012/01/how-the-us-convinced-spainto-adopt-internet-censorship.ars (accessed 8 January 2012).

Bennet, L. (2010). "Soitu.es couldn't find the business model to match its content creativity". Nieman Journalism Lab, 5 March, available at: http:// www.niemanlab.org/2010/03/soitu-es-couldnt-find-the-business-modelto-match-its-content-creativity/ (accessed 15 May 2012)

Casero, A., López, P. (2012). "La evolución de la agenda mediática española (1980-2010). Un análisis longitudinal de la portada de la prensa de referencia" Revista Latina de Comunicación Social, 67: 470-493.

CASERo, A.; Andrés, R. (2012). "Nuevas formas de producción de noticias en el entorno digital y cambios en el periodismo: el caso del 15-M". Comunicación y Hombre, 8: 130-140

Cabrera, M. A. (2012). Evolución Tecnológica y Cibermedios. Sevilla: Comunicación Social y Ediciones.

Comscore (2012). Number of European Smartphone Users Accessing News Surges 74 Percent Over Past Year. Available at: http://www.comscore.com/Press_ Events/Press_Releases/2012/3/Number_of_European_Smartphone_ Users_Accessing_News_Surges_74_Percent_Over_Past_Year (Accessed 10 May 2012).

EL PAís (2011). "La presión en la red contribuyó a tumbar la ley Sinde". 12 December, available at http://www.elpais.com/articulo/cultura/presion/ Red/contribuyo/tumbar/ley/Sinde/elpepucul/20111212elpepucul_2/ Tes (accessed 26 December 2011).

El PAís (2009). "La nueva OJD digital desata la polémica entre los grandes medios". 13 March, available at http://www.elpais.com/articulo/ sociedad/nueva/OJD/digital/desata/polemica/grandes/medios/ elpepisoc/20090313elpepisoc_7/Tes (accessed 10 March 2011).

Europa Press (2011). "España, pionera en la medición híbrida de audiencias online". 5 March, available at http://www.europapress.es/portaltic/internet/noticia-espana-pionera-medicion-hibrida-audiencias-online-20110305080009.html (accessed 15 March 2011). 
García, J. S. (2013). "Gobiernos en la calle y ciudadanos en las redes sociales: nuevas exigencias para el periodismo". Telos: Cuadernos de comunicación e innovación, (94), 58-67.

García, J. (2010). “¿Expulsar a los antisistema de Internet?”. El País. 5 October, available at http://www.elpais.com/articulo/cataluna/Expulsar/ antisistema/Internet/elpepuespcat/20101005elpcat_3/Tes (accessed 7 March 2011).

GARCíA, J. (2010). Internet, motor de los antisistema. El País, 7 October, available at http://www.elpais.com/articulo/cataluna/Internet/motor/antisistema/ elpepiespcat/20101007elpcat_8/Tes (accessed 7 March 2011).

Galera, M.; Del Hoyo Hurtado, M. (2013) "Redes sociales, un medio para la movilización juvenil". Zer: Revista de estudios de comunicación = Komunikąio ikasketen aldizkaria, 34: 111-125.

Idoyaga, P., Ramírez, T. (2012). "Política informativa de El País y ABC ante la nueva situación política del País Vasco (1998-2000)." Zer-Revista de Estudios de Comunicación 6.10

Llorens, C.; Luzón, V. \& Puertas, H. (2012). Mapping Digital Media: Spain. Avaliable at http://www.opensocietyfoundations.org/reports/mappingdigital-media-spain

Micò, J.l.; Canavilhas, J.; Masip, P. \& Ruiz, C. (2008).“La ética en el ejercicio del periodismo: Credibilidad y autorregulación en la era del periodismo en Internet". Estudos em Comunicaçao, Núm. 4, pàg. 15-39.

Otero, T. P., \& Sánchez, C. C. (2012). "Ciberactivismo y redes sociales. El uso de Facebook por uno de los colectivos impulsores de la 'spanish revolution', Democracia Real Ya (DRY)". Observatorio (OBS*), 6(3).

Presidencia del Gobierno (2011). Agenda de la Comunicación. Madrid: Gobierno de España, available at http://www.agenciasaeacp.es/publicaciones/ docs/AGENDA2011.pdf (accessed 20 April 2011).

Salaverría, R. \& Negredo, S. (2008). Periodismo integrado: convergencia de medios y reorganización de redacciones. Barcelona: Sol90Media.

Virgili, J. SÁDABA, T. (2007) "La construcción de la agenda de los medios. El debate del estatut en la prensa española." Ambitos: Revista internacional de comunicación, 16: 187-211.

ViLLANUEVA, J. et al. (2008). La TDT: ¿un negocio imposible? Barcelona: Deusto. 
